Bull. Geol. Soc. Finland 42, 23-32 (1970)

\title{
BIOTITES IN GRANITES, BIOTITES IN GNEISSES, AND THE STATUS OF BIOTITE AS A ONE-MINERAL ENVIRONMENT INDICATOR
}

\author{
Roland Gorbatschev
}

Dept. of Geology, Uppsala University and Geological Survey of Sweden

\section{ABSTRACT}

Some aspects of one-mineral geological environment indicators are discussed. Factors controlling the composition of biotite in different $\mathrm{P}, \mathrm{T}$, and chemical environments are reviewed. On the basis of theoretical considerations and empirical observation it is concluded that biotites in igneous granites may tend to be somewhat richer in iron than biotites from gneisses, but the relation is not strict, and the $\mathrm{Fe} / \mathrm{Mg}$ or $\mathrm{FeO} / \mathrm{MgO} / \mathrm{Al}_{2} \mathrm{O}_{3}$ ratios in biotite do not provide unequivocal indications of the origin of biotite-bearing rocks.

\section{Minerals as geological indicators}

A common approach to the problem of temperature, pressure, and provenance of material in petrogenesis is the investigation of intracrystalline chemical variations in mineral phases from different types of rock. The observed differences are then generalized to establish universally valid indicators. Familiar instances are observations of high concentration of $\mathrm{Mn}$ and/or Ca in low-grade garnets (Miyashiro 1953, Atherton 1965, and others), high $\mathrm{Mg}$ in garnets from granulites and eclogites, high contents of $\mathrm{Al}$ and $\mathrm{Ti}$ in highgrade amphiboles (Harry 1950, Leake 1965).

An inherent setback in using this "empirical» approach is the difficulty to appreciate the influence of changing rock composition as contrasted to intracrystalline variations depending on temperature, pressure, fugacity of volatiles, etc. A typical and fairly well investigated mindex mineral» is garnet, where the common observation of high $\mathrm{Ca}$ and $\mathrm{Mn}$ in low-grade garnets has been reversed to propose a one-mineral geological thermometer (Nandi 1967, Li-Ping Tan 1968). An implication must then be that $\mathrm{Mn}$ (and $\mathrm{Ca}$ ) either enter other minerals as temperature or pressure increase, or that there is wholesale loss of manganese from all rocks of higher facies. Difficulties of such an application of mineral composition are indicated by observations of garnets high in $\mathrm{Ca}$ and/or $\mathrm{Mn}$ in plutonics and in high-grade metamorphic rocks (Wright 1938, Clifford 1960, and others), and by studies of intermineral element distribution. Considering the particular case of $\mathrm{Mn}$ in garnet, the distribution of manganese between garnet and other common ferromagnesian silicates (Kretz 1959, Gorbatschev 1968, Saxena 1968 a and b, and others) suggests that $\mathrm{Mn}$ (and $\mathrm{Ca}$ ) stabilize the garnet lattice in preference to biotite, amphibole, and cordierite. Low-grade garnets close to the lower stability limits of this mineral at any particular $\mathrm{Fe} / \mathrm{Mg}$ will thus tend to form in rocks rich in $\mathrm{Mn}$ and $\mathrm{Ca}$. Since from experiments 
and studies of mineral associations garnet is on the high-grade side of reactions of the type:

biotite (or chlorite) + muscovite + quartz $\rightleftarrows$ garnet $+\mathrm{K}$-feldspar $+\mathrm{H}_{2} \mathrm{O}$ and

biotite $+\mathrm{Al}_{2} \mathrm{SiO}_{5}+$ quartz $\rightleftarrows$ garnet $+\mathrm{K}$ feldspar $+\mathrm{H}_{2} \mathrm{O}$,

the absolute amount of garnet in any particular isochemical rock composition will tend to increase with increasing grade, the rate depending among other things on the $\mathrm{Fe} / \mathrm{Mg}$ ratio and the activity of water. Consequently the attainment of higher metamorphic facies is accompanied by dilution of $\mathrm{Mn}$ in garnet and increase in $\mathrm{Mg}$, which does not needs imply that $\mathrm{Mn}$ is expelled from the garnet lattice. This is well in accord with observed changes of garnet composition in complex lithological sequences where variations of $\mathrm{Mn}$ and $\mathrm{Mg}$ in garnet with metamorphic grade are prominent, but differ between the various rock types as a function of total-rock composition (e.g. Velikoslavinsky 1965).

A considerably more rewarding approach than that of single-mineral indicators is the study of interphase element distribution, which is based on the fact that at equilibrium the chemical potential of a chemical species is the same in all coexisting phases. This provides a firm theoretical basis liable to treatment in strictly quantitative terms. Pioneered by Ramberg (1949), and Ramberg and De Vore (1951), numerous investigators have during the last decades shed light on crystal-chemical and environmental factors governing the distribution of elements between different coexisting mineral phases. Actually some useful »one-mineral indicators», as for instance the contents of $\mathrm{Ti}$ in biotite or amphibole or magnetite, can be considered more strictly as cases of the intermineral distribution model.

Somewhat more evasive are indicators of "geological provenance» of chemical components which enter rocks and minerals. The basis of reasoning is here that certain geological processes have compositional or structural consequences of such a frequency and regularity as to make them eligible for use as guides in the interpretation of petrogenetical problems. A common and longpursued approach has been the observation of compositional parameters of minerals and rocks and their attribution to certain environments of formation. Considering the particular case of biotite, differences between groups of biotites from different types of rock have been observed by a.o. Heinrich (1946) and Rimšaite (1964), and have recently been proposed as means of discriminating between granites of »igneous» and »metamorphic» origin (Gokhale 1968). This potential employment of biotite as a one-mineral provenance indicator is entirely dependent on the regularity of the observed compositional variation, preferably augmented by the theoretical recognition of processes which exclude certain biotite compositions from products of either igneous crystallization or metamorphic-metasomatic granitization. Some aspects of the problem are discussed here.

\section{Some theoretical considerations}

While the $\mathrm{Fe} / \mathrm{Mg}$ proportions of biotites may reflect the whole-rock $\mathrm{Fe} / \mathrm{Mg}$ ratio there is a number of other factors which may have equal or greater importance. At equilibrium any rock will have the mineral composition corresponding to a minimum of free energy. The equilibrium distribution of elements between different mineral phases implies equality of chemical potential $(\mu)$ of a species $i$ in all host minerals:

$\mu_{i}^{\mathrm{a}}=\mu_{i}^{\mathrm{b}}=\mu_{i}^{\mathrm{c}} \ldots=\mu_{i}^{\mathrm{n}}$

where $\mathrm{a}, \mathrm{b}, \mathrm{c} \ldots \mathrm{n}$ are mineral phases. The chemical potential of a chemical species is determined by concentration, temperature, and pressure according to:

$$
\mu_{i}=\mathrm{sdT}+\mathrm{vdP}+\mathrm{RT} \ln f \mathrm{X}
$$

where $\mathrm{s}$ is entropy, $\mathrm{v}$ specific volume, $\mathrm{X}$ concentration, $f$ activity coefficient, and $\mathrm{R}$ the gas constant. 
In minerals of variable composition other chemical components may alter the lattice dimensions and properties of bonding, and thus the lattice energetics and according to (2) and (1) the affinity of a mineral phase for a particular chemical species.

The equilibrium distribution of $\mathrm{Fe}$ and $\mathrm{Mg}$ between different coexisting minerals must conform with the requirement imposed by (1) and can be described by the distribution coefficient $\left(\mathrm{K}_{\mathrm{D}}\right)$ defined as:

$\mathrm{K}_{\mathrm{D}_{\mathrm{Fe}}^{\mathrm{ab}}}=\frac{\mathrm{X}_{\mathrm{Fe}}^{\mathrm{a}}}{\mathrm{X}_{\mathrm{Mg}}^{\mathrm{a}}} \quad \mathrm{X}_{\mathrm{Mg}}^{\mathrm{b}}=\mathrm{Ka} \exp \left(-\triangle \mathrm{G}_{(4)} / \mathrm{RT}\right)$

where $\mathrm{X}$ are the mole fractions in phases $\mathrm{a}$ and $\mathrm{b}$, $\mathrm{Ka}$ is an activity coefficient term and $\triangle G_{(4)}$ is the increase of free energy for the exchange reaction

$\mathrm{Fe}^{\mathrm{a}}+\mathrm{Mg}^{\mathrm{b}} \rightleftarrows \mathrm{Fe}^{\mathrm{b}}+\mathrm{Mg}^{\mathrm{a}}$

In case of ideal distribution the term $\mathrm{Ka}$ is equal to unity and the distribution coefficient is a constant for any constant combination of $\mathrm{T}$ and P. If the lattices of two coexisting mineral phases are crystal-chemically similar, the effect of changing $\mathrm{P}-\mathrm{T}$ conditions will be more or less inefficient as a grade indicator. This is the case e.g. in coexisting biotite and $\mathrm{Ca}$-amphibole where the response of iron-magnesium $\mathrm{K}_{\mathrm{D}}$ to changing $\mathrm{P}$ and $\mathrm{T}$ is much weaker than its variation as a function of ( $\mathrm{Si}, \mathrm{Al}$, and $\mathrm{Ti}-$ ) substitutions in tetrahedral or octahedral sites.

To survey compositional and environmental factors influencing the composition of biotites in granites and metamorphic rocks we will next consider the distribution of $\mathrm{Fe}$ and $\mathrm{Mg}$ between biotite and other relevant minerals.

For the purpose of this paper $K_{D}$ for coexisting biotite and $\mathrm{Ca}$-amphibole can be regarded as being approximately unity, which implies that Ca-amphibole coexisting with biotite at equilibrium will have little effect on the biotite $\mathrm{Fe} / \mathrm{Mg}$ parameter. Because $\mathrm{M}_{4}$ sites in orthoamphibole take $\mathrm{Fe}$ in preference to $\mathrm{Mg}$, the distribution of iron is shifted somewhat in favor of that mineral. Nevertheless, the shift from unity is comparatively small, the distribution coefficient $\mathrm{K}_{\mathrm{D}_{\mathrm{Fe}}}^{{ }^{\mathrm{i}-\mathrm{a}}}$ being approximately $1.2-1.4$ in the $\mathrm{X}_{\mathrm{Fe}}$ concentration range considered here (Gorbatschev unpublished data).

Other important ferromagnesian minerals commonly coexisting with biotite are garnet, cordierite, and chlorite. Pyroxene and $\mathrm{Fe}-\mathrm{Mg}$ spinels are of considerably less importance whether granites or granitization products are concerned. Staurolite and chlorite may occur in large quantities, but are for most relevant $\mathrm{Fe} / \mathrm{Mg}$ proportions restricted to low-grade rocks. Since staurolite carries iron in 4-coordination, which is a type of lattice site not easily occupied by $\mathrm{Mg}$ in silicates, the distribution of $\mathrm{Mg}$ is anticipated to be strongly in favor of biotite as is confirmed by Green's (1963) and Hounslow and Moore's (1967) data, the latter giving $\mathrm{K}_{\mathrm{D}_{\mathrm{Fe}}^{\text {stur-bi }}} \approx 4.0$. Somewhat higher $\mathrm{K}_{\mathrm{D}_{\mathrm{Fe}}}$ (4 to 6) have been found for coexisting $\mathrm{Mg}-\mathrm{Fe}-\mathrm{Al}$ spinel and biotite (Gorbatschev unpublished data). The variation of $K_{D}$ with temperature has not been investigated, but may be expected to be prominent. Due to the uncommonness of spinel — which is often stabilized by small amounts of $\mathrm{Zn}$ and for reasons of the restricted $\mathrm{P}-\mathrm{T}$ field of staurolite occurrence, $K_{D}$ variations with temperature are of little concern here. Data on biotite-chlorite pairs are scarce and not wholly unambiguous. Because of the general similarity of the biotite and chlorite lattices, $K_{D}$ does probably not depart very much from unity which is in accord with the actinolite-chlorite data of Ramberg (1952). Extensive possibilities of intramineral element substitutions indicate susceptibility of $\mathrm{K}_{\mathrm{De}}^{\text {bi-chl. }}$ to compositional influences.

The distribution of $\mathrm{Fe}$ and $\mathrm{Mg}$ between biotite, cordierite, and garnet is well elaborated. Cordierite has long been known to be a more mag- 
nesiophile mineral than garnet (Folinsbee 1941)

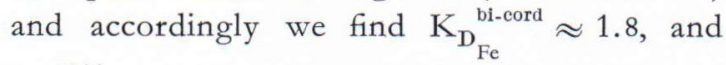
$\mathrm{K}_{\mathrm{D}}^{\mathrm{gt}-\mathrm{bi}}$ ranging between approximately 9 and 2 (Gorbatschev 1968, Saxena 1968 a, and numerous other papers). Because of the basically different crystal lattices of garnet and biotite we may anticipate a different response to changing temperature, which is confirmed by $\mathrm{K}_{\mathrm{Fe}}^{\text {gt-bi }}$ being approximately 9.0 in epidote-amphibolite and 5.6 in upper amphibolite to granulite facies (Saxena 1968 a and b). Studies of coexisting garnets and biotites in the Svecofennian basement of Finland and Sweden suggest the following data: transition epidote-amphibolite to amphibolite facies $\sim 7$ to 7.5 , transition between andalusite and sillimanite grade at pressures of regional metamorphism in buried geosynclinal sediments $\left(600^{\circ}-630^{\circ} \mathrm{C}\right.$, Althaus 1967) $\sim 6$, uppermost amphibolite- hornblende granulite facies 3-4, aggregation of veins in veined gneisses into independent pegmatite-granite bodies 3-3.5. The highest values yet recorded $\left(\mathrm{K}_{\mathrm{D}} \leq 2.5-3\right)$ are from intensely granite-veined gneisses and some granulites (Gorbatschev unpublished data, Kostyuk 1955, and inferrences from Eskola 1952). The above data refer to garnets low in $\mathrm{Ca}$ and $\mathrm{Mn}$. The $\mathrm{Fe} / \mathrm{Mg}$ distribution between garnet and biotite is sensitive to variations of the $\mathrm{Mn}$-concentration in garnet (Kretz 1959, Saxena 1968 b), to $\mathrm{Al}$, Ti, and possibly the occupancy of octahedral layers in biotite, and may be somewhat non-ideal (Dahl 1969, Saxena 1969, Gorbatschev 1968). Except for cases of extremely Mn-rich garnet all these factors are numerically of less importance than the dependence on temperature, the effect of pressure being slight (Kretz 1963).

We conclude from the above that as far as the distribution of iron between biotite and coexisting ferromagnesian silicates is concerned, lowoxidized granite biotites are apt to represent closely the whole-rock silicate-iron/magnesium ratio, while the nature of coexisting mineral phases is of paramount importance in many metamorphic rocks. In aluminous rocks the effects of garnet and staurolite combine to produce "too low» iron in biotites as compared to the anticipated biotite compositions in granitization products which have resulted from the dilution of $\mathrm{Al}$ by alkalies, but preserve the $\mathrm{Fe} / \mathrm{Mg}$ ratio basically unchanged. This trend is to some extent counterbalanced or may even be outweighed by cordierite in extremely aluminous and rather magnesium-rich paragneisses. Naturally the numerical relation between the $\mathrm{Fe} / \mathrm{Mg}$ composition of biotites and the whole-rock $\mathrm{Fe} / \mathrm{Mg}$ ratio will depend on the absolute amounts of the different ferromagnesian phases, which are controlled not only by metamorphic grade ( $\sim$ temperature) and the $\mathrm{Fe} / \mathrm{Mg}$ ratio in the rock, but also by the availability of e.g. $\mathrm{Ca}$ and $\mathrm{Mn}$ - which stabilize garnet - and $\mathrm{H}_{2} \mathrm{O}$ and Ti which stabilize biotite and may increase the variance of the whole system.

In addition to rock bulk composition and the nature of coexisting phases the $\mathrm{Fe} / \mathrm{Mg}$ ratio in silicates is highly sensitive to the oxidation potential of the environment. For the decomposition reaction of biotite:

$$
\begin{aligned}
& \mathrm{KFe}_{3} \mathrm{AlSi}_{3} \mathrm{O}_{10}(\mathrm{OH})_{2}+1 / 2 \mathrm{O}_{2} \rightleftharpoons \mathrm{KAlSi}_{3} \mathrm{O}_{8} \\
& +\mathrm{Fe}_{3} \mathrm{O}_{4}+\mathrm{H}_{2} \mathrm{O}
\end{aligned}
$$

which can also be written:

$\mathrm{KFe}_{3} \mathrm{AlSi}_{3} \mathrm{O}_{10}(\mathrm{OH})_{2} \rightleftharpoons \mathrm{KAlSi}_{3} \mathrm{O}_{8}+\mathrm{Fe}_{3} \mathrm{O}_{4}$
$+\mathrm{H}_{2}$

the condition of equilibrium is:

$\Delta \mathrm{G}_{(6)}=\mathrm{O}=\mathrm{G}_{\mathrm{Kfsp}}+\mathrm{G}_{\mathrm{mt}}+\mu_{\mathrm{H}_{2}}-\mu_{\mathrm{ann}}$

and since $\mu_{\text {ann }}=\mathrm{G}_{\text {ann }}+\mathrm{RT} \ln f_{\mathrm{ann}} \mathrm{X}_{\mathrm{ann}}$,

we obtain by transforming:

$\mathrm{X}_{\mathrm{ann}}=\frac{1}{f_{\mathrm{ann}}} \exp \left(\frac{\Delta \mathrm{G}_{(6)}^{\circ}+\mu_{\mathrm{H}_{2}}}{\mathrm{RT}}\right)$, 
which implies that the mol fraction of annite in biotite solid solution is a function of temperature, pressure, and the chemical potential of $\mathrm{H}_{2}$. At constant temperature and pressure the oxidizing conditions of geological environments thus impose restrictions on the maximum possible iron contents of biotite. Exhaustive theoretical and experimental consideration of Fe-biotite stability is given by Wones and Eugster (1965).

High activity of $\mathrm{H}_{2} \mathrm{O}$ promotes the formation of biotite and from reactions of the following type:

$\mathrm{KFe}_{2}^{3+} \mathrm{AlSi}_{3} \mathrm{O}_{10}(\mathrm{OH})_{2} \rightleftharpoons \mathrm{Fe}_{2} \mathrm{O}_{3}+\mathrm{KAlSi}_{3} \mathrm{O}_{8}$ $+\mathrm{H}_{2} \mathrm{O}$

and $4 \mathrm{KFe}_{0 \cdot 75}^{2+} \mathrm{Fe}_{1 \cdot 5}^{3+} \mathrm{AlSi}_{3} \mathrm{O}_{10}(\mathrm{OH})_{2} \rightleftharpoons 3 \mathrm{Fe}_{3} \mathrm{O}_{4}$ $+4 \mathrm{KAlSi}_{3} \mathrm{O}_{8}+4 \mathrm{H}_{2} \mathrm{O}$

we find $\mathrm{X}_{\text {ferribi }}=\frac{1}{f_{\text {ferribi }}} \exp \left(\frac{\Delta \mathrm{G}_{(9)}^{\circ}+\mu_{\mathrm{H}_{2} \mathrm{O}}}{\mathrm{RT}}\right)$

and $\quad \mathrm{X}_{\mathrm{bi}_{(10)}}=\frac{1}{f_{\mathrm{bi}_{(10)}}} \exp \frac{\Delta \mathrm{G}^{\circ}{ }_{(10)}+4 \mu_{\mathrm{H}_{2} \mathrm{O}}}{4 \mathrm{RT}}$

which informs us that the composition of biotite is a function of the chemical potential of $\mathrm{H}_{2} \mathrm{O}$.

For sulphidization we similarly find restrictions on maximum possible iron in silicates as functions of $\mu_{\mathrm{H}_{2} \mathrm{~S}}, \mu_{\mathrm{S}_{2}}$, and $\mu_{\mathrm{SO}_{2}}$.

\section{Mineral data}

To survey the parentage of biotites rich and intermediate in iron, which have been claimed to define the fields of igneous granites and metamorphic rocks, data from some recently analyzed or published groups of biotites from well-investigated rocks have been plotted in Figs. 1 and 2 . From the diagrams in Gokhale's paper (1968) it is evident that the alleged main difference is in the $\mathrm{Mg} / \mathrm{Fe}^{2+}$ ratio, but in order to allow direct comparisons with previously published data and since iron in many analytical techniques is determined as total $\mathrm{Fe}$, the mode of presentation adopted here is by the kind of diagrams employed by Nockolds (1947). With the possible exception of one sample (Grey Revsund, cf. Gorbatschev 1969) the parent granites of the biotites in Fig. 1 are considered to be »igneous», two of the groups - Rätan and Graversfors - being clearly crosscutting and somewhat later than the main phase of migmatization and associated folding in the concerned areas. Indeed, the Rätan granite is taken to be »older post-orogenic» in its regional context (Lundqvist 1967). The Ben Nevis granites studied by Haslam (1968) are part of a complex quartz-diorite - granite intrusion. The biotites of the Ben Nevis quartz-diorite are similar to the dark mica in the granite, but have not been plotted in Fig. 1 which is limited to rocks of the granite clan proper. The detached left-side pegmatite entry in Fig. 1 represents a rock associated with Grey Revsund granite (Gorbatschev 1969), while the other Svecofennian pegmatite ( $\mathrm{MgO}$-proportion in biotite 14.9) is a garnetiferous isolated lump in migmatized terrain. The rest of the pegmatites are Alpine (Schwander et al. 1968).

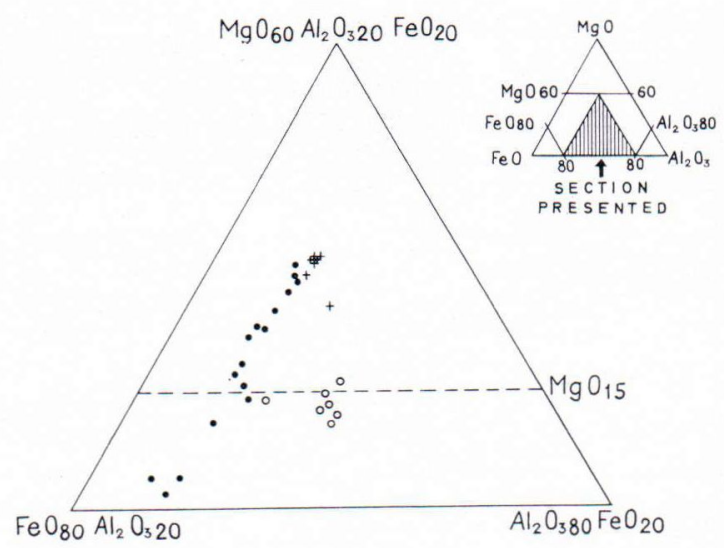

Fig. 1. $\mathrm{MgO}-\mathrm{Al}_{2} \mathrm{O}_{3}-\mathrm{Fe}_{\text {to }}$ al $=\mathrm{FeO}$ plot of biotites from granites and pegmatites. Signs: crosses $=$ granites and acid quartz-diorites from Ben Nevis (Haslam 1968), open circles = Alpine and Svecofennian pegmatites (Schwander et al. 1968, Gorbatschev unpublished), dots = granites (Gorbatschev 1969). The line at $\mathrm{MgO}=15$ delimits the magmatic field of Gokhale (1968). 
Together the data plotted in Fig. 1 combine to show that some of the most characteristically »igneous» granites in the Svecofennian basement of Scandinavia carry biotites well inside the allegedly metamorphic field. Considering two other complexes of igneous granites, total-rock chemical analyzes of Finnish rapakivis suggest high $\mathrm{Fe}$ in their biotites, whereas the Dala granites of Sweden, while exhibiting $\mathrm{MgO} / \mathrm{MgO}+$ $\mathrm{FeO}$ ratios of $0.1-0.3$ have $\mathrm{Fe}^{3+} / \mathrm{Fe}^{3+}+\mathrm{Fe}^{2+}$ around or above 0.5 (Lundqvist 1967) and the biotites mentioned to occur in these rocks must consequently be highly magnesian. The inclusion of tonalites, quartz-diorites etc, would greatly increase the number of entries in the central and upper parts of Fig. 1.

Figure 2 is a plot of biotites from metamorphic rocks, most of them of clearly evidenced sedimentary derivation. While some of the biotites, particularly those from Moldanubian gneisses in the border area between Czechoslovakia and Germany, are associated with cordierite plus garnet and spinel, most of the Svecofennian biotites have been analyzed for studies of element distribution in garnet and biotite and are associated with garnet only. They may thus be anticipated

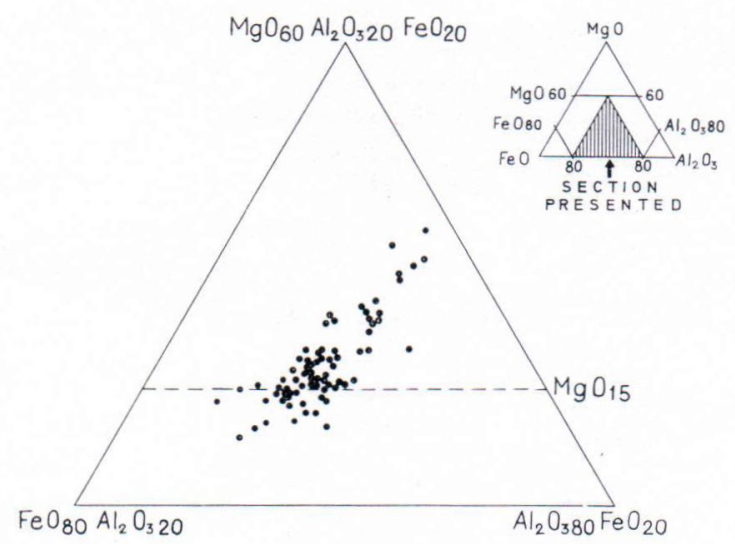

Fig. 2. $\mathrm{MgO}-\mathrm{Al}_{2} \mathrm{O}_{3}-\mathrm{Fe}_{\text {total }}=\mathrm{FeO}$ plot of biotites from schists and gneisses. Sources: Butler (1967), Moine schists; Hounslow and Moore (1967), Grenville schists; Schwander, Hunziker, Stern (1968), Alpine schists and gneisses; Gorbatschev unpublished, Svecofennian and Moldanubian gneisses and schists. The line at $\mathrm{MgO}=15$ demarcates the magmatic field of Gokhale (1968). to be less ferruginous than biotites in similar rocks below the "garnet-grade» or biotites produced during metasomatic addition of alkalies in granitization. To give the separation into igneous and metamorphic biotite fields the benefit of doubt, no analyzed biotites from Svecofennian leptite-gneisses (acid metavolcanics and metaarkoses) have been included. Generally these rocks have somewhat higher $\mathrm{Fe} / \mathrm{Mg}$ ratios than schists, metagreywackes, and argillaceous paragneisses.

It must be emphasized here that neither Fig. 1 nor Fig. 2 purport to represent a statistically as unbiased as possible review of the compositional variations in biotite as depending on rock parentage. The aim is here not to investigate the averages and variances of biotites in different groups of rocks, but rather to consider the problem of whether there is an unequivocal separation into paragneiss and orthoigneous fields of biotite composition on the basis of $\mathrm{MgO}$ contents, which could provide a provenance indicator to be used without excessive reservations and hesitation. Biotites from rock groups not relevant for the tackling of this problem have been deliberately excluded. Plotting all available granites and all available paragneisses would demonstrate a statistically significant difference between the group averages. Again, it should be noted that the inclusion of all metamorphic rocks, para- as well as orthogneisses of volcanic and plutonic provenance, tends to oblitterate the differences between biotites of metamorphic-metasomatic and igneous origin. Actually, a consideration of all metamorphic rocks is of greater interest when dealing with the general composition of granitization products than a restriction to metaargillites only.

\section{Discussion and conclusions}

Factors which control the composition of biotites have been discussed in the preceding sec. tions. In anhydrous silicates coexisting with iron 
oxides the $\mathrm{Mg} / \mathrm{Mg}+\mathrm{Fe}^{2}+$ ratio permits the determination of univariant $\mathrm{p}_{\mathrm{O}}^{*}\left(\mathrm{p}^{*}=\right.$ fugacity $)$ conditions. The controls of $\mathrm{Mg} / \mathrm{Mg}+\mathrm{Fe}^{2+}$ in biotite are described by reaction (5), and the decisive factor is the relation between the chemical potentials of oxygene and water, which can be rewritten to give (8). Because chemical analyses indicate that biotite accommodates ferric iron as »oxybiotite» plus di-octahedral »ferrimica» end-members, the $\mathrm{Mg} / \mathrm{Mg}+\mathrm{Fe}_{\text {total }}$ ratio will vary as a function of water fugacity as suggested by equations of type (11) and (12). At high hydrogene fugacities all ferric iron may be accommodated in biotite (and other silicates) and the $\mathrm{Mg} / \mathrm{Mg}+\mathrm{Fe}_{\text {total }}$ ratio will reflect rock bulk composition and the distribution of iron between silicate phases. The critical aseemblage which permits the determination of univariant $\mathrm{p}_{\mathrm{H}}^{*}-\mathrm{T}$ conditions of equilibrium from biotite compositions must thus include all the solid components of reation (6). In other cases biotite composition only indicates lowest possible $\mathrm{P}_{2}^{*}$ at known $\mathrm{T}$.

Relations between the oxidation state of iron and $\mathrm{X}_{\mathrm{Mg}}$ in whole-rock and biotite analyses of some granites are given in Table 1 . All included biotites coexist with amphibole. Rocks of the Rätan group and granites L 55 and 15558 in

TABLE 1

Some total-rock and biotite parameters of analyzed granites.

\begin{tabular}{|c|c|c|c|c|}
\hline \multirow{3}{*}{$\begin{array}{l}\text { Specimen nr. } \\
\text { (Gorbatschev 1969) }\end{array}$} & \multicolumn{3}{|c|}{ Whole rock } & \multirow{3}{*}{$\frac{\text { Biotite }}{\frac{\mathrm{Mg}}{\mathrm{Mg}+\mathrm{Fe}_{\text {tota }}}}$} \\
\hline & $\mathrm{Fe}^{3+}$ & $\mathrm{Mg}$ & $\mathrm{Mg}$ & \\
\hline & $\mathrm{Fe}^{3+}+\mathrm{Fe}^{2+}$ & $\left|\overline{\mathrm{Mg}+\mathrm{Fe}_{\text {total }}}\right|$ & $\mathrm{Mg}+\mathrm{Fe}^{2+}$ & \\
\hline \multirow{7}{*}{$\begin{array}{c}\text { Rätan granite } \\
66 / 198 \ldots \ldots \\
66 / 42 \ldots \ldots \\
15286 \ldots \\
66 / 122 \ldots \\
66 / 104 \ldots \\
66 / 87 \ldots \\
. . . .\end{array}$} & & & & \\
\hline & 0.46 & 0.40 & 0.55 & 0.59 \\
\hline & 0.44 & 0.39 & 0.53 & 0.57 \\
\hline & 0.45 & 0.38 & 0.52 & 0.55 \\
\hline & 0.36 & 0.34 & 0.44 & 0.46 \\
\hline & 0.37 & 0.34 & 0.45 & 0.45 \\
\hline & 0.42 & 0.32 & 0.44 & 0.51 \\
\hline \multicolumn{5}{|l|}{ Other granites } \\
\hline $15298 \quad \ldots$ & 0.18 & 0.32 & 0.37 & 0.32 \\
\hline L $55 \quad \ldots$. & 0.29 & 0.31 & 0.38 & 0.35 \\
\hline $15558 \ldots$ & 0.21 & 0.26 & 0.30 & 0.25 \\
\hline $15299 \quad \ldots$ & 0.14 & 0.15 & 0.17 & 0.10 \\
\hline $15293 \ldots$ & 0.13 & 0.09 & 0.11 & 0.10 \\
\hline
\end{tabular}

addition contain magnetite (plus microcline and quartz). Disregarding possible effects of substitutions other than $\mathrm{Mg} \leftrightarrows \mathrm{Fe}$, the $\mathrm{Fe} / \mathrm{Mg}$ ratio of the ferromagnesian silicate phases in these samples is determined by $\mathrm{p}_{\mathrm{H}}^{*}-\mathrm{T}$. In the other granites magnetite is absent or found in trace amounts in cracks, and may not be in equilibrium with the ferromagnesian silicates. As demonstrated previously, the occurrence of coexisting amphibole influences biotite composition but slightly, and the low-oxidized samples show close agreement between $\mathrm{Mg} / \mathrm{Fe}_{\text {iotal }}$ in biotite and bulk analyses. High Fe in biotite 15299 is probably due to coexisting chlorite which takes somewhat more $\mathrm{Mg}$ than does biotite.

Reverting to the composition of biotites in specific groups of rocks, we infer from the averages compiled by Pettijohn (1957) that sedimentary differentiation is usually not very efficient in separating $\mathrm{Fe}$ and $\mathrm{Mg}$ in greywackes, subgreywackes, and shales, while arkoses and orthoquartzites are strongly enriched in iron. To some extent these differences may result from the composition of source-rocks and particularly the influx of ophiolitic-spilitic basic material into the provenance areas of the greywacke suite. In rocks where ferromagnesian silicates do not coexist with iron oxides the composition of biotites depends on rock composition and intermineral element distribution. The data in Fig. 2 demonstrate that $\mathrm{p}_{\mathrm{H}}^{*}$ is in many cases sufficiently high to allow the formation of iron-rich biotites. We conclude that the formation of spseudoigneous» plutonics by a metamorphic-metasomatic process which, as suggested by Peikert (1964), does not affect original differences in oxidation, must result in a range of different oxidation states and in biotites with different $\mathrm{Fe} /$ $\mathrm{Mg}$ ratios. As can be inferred from Fig. 2, some of these will be low in $\mathrm{Mg}$. In the rocks investigated by Peikert (1964) R.I. (= refractive index) of biotite had been measured to determine the oxidation state i.e. more precisely $\mathrm{PO}_{2}^{*} / \mathrm{P}_{2}^{*} \mathrm{O}$ at known or estimated temperature. Here the 
strongest argument in favor of non-igneous formation is the areal pattern of R.I. distribution rather than the R.I. measure by itself. Further, Peikert's rocks are granodiorites, quartzdiorites, and quartz-monzonites, not granites sensu stricto, and the inclusion of igneous counterparts of such rocks in Fig. 1 would place most of them in the field alleged to be characteristic of metamorphic provenence. A good example are rocks of the well-investigated South California batholith (Larsen 1948, Larsen and Draisin 1948) which show enrichment of iron in biotites of late granites, but where the biotites of tonalites and granodiorites have $\mathrm{MgO} \geq 20$ in terms of the diagram type employed in Figs. 1 and 2. Similar trends appear to prevail in the Early Svecofennian suites of differentiated plutonics in Fennoscandia and in members of the postorogenic Rapakivi suite. Incidentally biotite compositions in these rocks must imply that $\mathrm{p}_{2}^{*} / \mathrm{PO}_{2}^{*}$ increases as differentiation proceeds. Again, there are groups of rhyolitic effusives and »intrusive» granites which have low bulk $\mathrm{Fe} / \mathrm{Fe}+\mathrm{Mg}$ and thus necessarily must contain magnesian biotites, no matter what the oxidation state. Characteristic instances in Sweden are some »hälleflinta» volcanics (Sundius 1923) and granites of Rätan, Filipstad, and Järna types. As mentioned previously the latter rocks behave clearly intrusively into their environment, even cutting across boundaries between diversely metamorphosed terranes allegedly belonging to different »orogenic belts». From the general homogeneity and the pattern of subordinate compositional variations, they are not metamorphic-metasomatic in the sense of having been produced in situ. It may be noted that these groups characteristically are poor in associated gabbroid differentiates. It is, however, outside the scope of this paper to discuss their origin beyond the statement of extreme improbability of in situ granitization. Undifferentiated synkinematic Late-Svecofennian granites associated with regional migmatization (the Stockholm group and allied types) are com- monly reckoned as formed by a combination of granitization in situ, partial melting, and igneous intrusion. Since the numerous older analyses of these rocks usually do not differentiate between different modes of origin, they are of little value in the present context. From analyses in e.g. Stålhös' paper (1962) it can nevertheless by concluded that most varieties, regardless whether of granitization or locally intrusive »igneous» origin, are too high in $\mathrm{Mg} / \mathrm{Fe}$ to qualify for the »igneous» field. The same also applies to isolated massives of similar granites intruding into low-grade terrains outside of the main belt of folding.

To sum up, biotites coexisting with other ferromagnesian minerals are valuable checks of equilibrium distribution of elements and can in some instances, e.g. in association with garnet or titanium oxides, be employed as geological thermometers. In mineral assemblages which include iron oxides the $\mathrm{Mg} / \mathrm{Mg}+\mathrm{Fe}^{2}+$ parameter of biotites defines the univariant $\mathrm{p}_{\mathrm{H}_{2}}^{*}-\mathrm{T}$ conditions of equilibrium. However, the chemical composition of biotites is no good general indicator of granite formation by either »igneous» intrusion or metamorphism. Exceptions in relation to most metamorphic terrains may be the extremely iron-rich late acid members of differentiated plutonic suites. The salient difference is here one of bulk $\mathrm{X}_{\mathrm{Fe}}$ rather than state of oxidation. From studies of intermineral distribution of elements it is evident that granites cannot produce biotites which greatly exceed the rock $\mathrm{Fe} / \mathrm{Mg}$, no matter what the $\mathrm{p}_{\mathrm{H}_{2}}^{*}$ status. The defining characteristic is thus a matter of whole rock rather than biotite composition. While there may be differences between the average compositions of biotites from metamorphic rocks and from igneous granites, the comparison of these measures has little relevance in considering the critical area of biotites poor and intermediate in $\mathrm{Mg}$. Most of the extremely magnesian metamorphic biotites stem from highly oxidized ironformations, which are either quantitatively un- 
important or uncontroversial from the point of view of granitization.

Basically, the problem of iron-magnesium relations in biotite can be subdivided to concern the $\mathrm{Mg} / \mathrm{Fe}^{2+}$ and $\mathrm{Mg} / \mathrm{Fe}_{\text {total }}$ parameters, respectively. At low $\mathrm{P}_{\mathrm{H}_{2}}^{*}$ both will be functions of the oxidation state. At high $\mathrm{p}_{\mathrm{H}_{2}}^{*}$ the $\mathrm{Mg} / \mathrm{Fe}^{2+}$ ratio will still be a measure of oxidation, while $\mathrm{Mg}$ / $\mathrm{Fe}_{\text {total }}$ may become a function of rock composition and element distribution. If the critical difference between two rock groups is in the bulk contents of $\mathrm{Fe}$ and $\mathrm{Mg}$, then $\mathrm{Mg} / \mathrm{Fe}_{\text {total }}$ will be the proper measure to investigate. However, for this purpose and to evaluate the amount of $\mathrm{Al}$, bulk analyses of rock specimens are the rational approach because they provide more relevant information on these particular aspects and in most analytical procedures involve less effort than the separation and analysis of minerals. If again, $\mathrm{p}_{\mathrm{H}_{2}}^{*}$ is assumed to be the critical factor, the proper measures are $\mathrm{Fe}^{2+} / \mathrm{Mg}$ or $\mathrm{Fe}^{2+} / \mathrm{Fe}^{3+}$. Investigation of these parameters in minerals is of utmost importance for the understanding of geological processes. However, in the present case, differences in biotite oxidation state have not been claimed to be a critical point in distinguishing between granites of different origin (Diagram 1 in Gokhale 1968).

Acknowledgments - Numerous chemical data quoted in this paper have been obtained by analytical work on the Geoscan electron probe at the Dept. of Geology in Uppsala, sponsored financially by grants from Malmfonden (87) and Naturvetenskapliga Forskningsrådet (nr. 2392-17).

Address of the author: Dept. of Mineralogy and Geology, Uppsala University, Box 555, S75122 Uppsala 1, Sweden.

\section{REFERENCES}

Althaus, E. (1967) The triple point andalusite-sillimanite-kyanite. Contrib. Miner. Petrol. 16, 29-44.

Atherton, M. P. (1965) The composition of garnet from regionally metamorphosed rocks. In »Controls of Metamorpbism», 281-290. Oliver \& Boyd.

Butler, B. C. M. (1967) Chemical study of minerals from the Moine Schists of the Ardnamurchan area, Argyllshire, Scotland. J. Petrol. 8, 233-267.

Clifford, T. N. (1960) Spessartine and magnesium biotite in coticule-bearing rocks from Mill Hollow, Alstead Township, New Hampshire, USA. N. Jb. Miner. Abb. 94, 1369-1400.

DAHL, O. (1969) Irregular distribution of iron and mangnesium among coexisting biotite and garnet. Lithos 2, 311-322.

Eskola, P. (1952) On the granulites of Lapland. Amer. J. Sci. Bowen volume, 133-171.

Folinsbee, R. E. (1941) The chemical composition of garnet associated with cordierite. Amer. Miner. 26, $50-53$.

Gokhale, N. W. (1968) Chemical composition of biotites as a guide to ascertain the origin of granites. Bull Geol. Soc. Finland 40, 107-111.

Gorbatschev, R. (1968) Distribution of elements between cordierite, biotite, and garnet. N. Jb. Miner. Abb. 110, 57-80.
- (1969) Element distribution between biotite and Ca-amphibole in some igneous or pseudoigneous rocks. N. Jb. Miner. Abh., 111, 314-342.

Green, J. C. (1963) High-level metamorphism of pelitic rocks in northern New Hampshire. Amer. Miner. 48, 991-1023.

Harry, W. T. (1950) Aluminium replacing silicon in some silicate lattices. Miner. Mag. 29, 142-149.

Haslam, H. W. (1968) The crystallization of intermediate and acid magmas at Ben Nevis, Scotland, J. Petrol. 9, 84-104.

Heinrich, E. Wm. (1946) Studies in the mica group; the biotite-phlogopite series. Amer. J. Sci. 244, 836-848.

Hounslow, A. W. \& Moore Jr., J. M. (1967) Chemical petrology of Grenville schists near Fernleigh, Ontario. J. Petrol. 8, 1-28.

Kostruk, V. P. (1955) Paragenetical analysis of Podolian crystalline schists in the Vinniza area. (In Russian). Kiev.

Kretz, R. (1959) Chemical study of garnet, biotite, and hornblende from gneisses of south-western Quebec, with emphasis on distribution of elements in coexisting minerals. J. Geol. 67, 371-402.

- (1963) Distribution of magnesium and iron between orthopyroxene and calcic pyroxene in natural mineral assemblages. J. Geol. 71, 773-785. 
LARsEn, E. S. JR. (1948) Batholith and associated rocks, of Corona, Elsinore, and San Luis Rey quadrangless Southern California. Geol. Soc. Amer., Memoir 29.

- \& Draisin, W. M. (1948) Composition of the minerals in the rocks of the Southern California Batholith. 18 th Int. Geol. Congr. Great Britain. Reports, part 2, 66-79.

LEAKE, B. E. (1965) The relationship between composition of calciferous amphibole and grade of metamorphism. In "Controls of Metamorpbism», 299-318. Oliver \& Boyd.

Lundevist, T. (1967) Precambrian Geology of the LosHamra region. Central Sweden. Sveriges Geol. Unders. Ser. Ba No. 23.

Miyashiro, A. (1953) Calcium-poor garnet in relation to metamorphism. Geochim. et Cosnochim. Acta 4, $179-200$.

Nand, K. (1967) Garnets as indices of progressive regional metamorphism. Miner. Mag. 36, 89-93.

Nockolds, S. R. (1947) The relation between chemical composition and paragenesis in the biotite micas of igneous rocks. Amer. J. Sci. 245, 401-420.

- (1966) The behaviour of some elements during fractional crystallization of magma. Geochim. et Cosmocbim. Acta 30, 267-278.

Peikert, E. W. (1963) Biotite variation as a guide to petrogenesis of granitic rocks in the Precambrian of northeastern Alberta. J. Petrol. 4, 18-54.

Petrijohn, F. J. (1957) Sedimentary rocks. 2nd ed. Harper \& Row.

RamberG, H. (1949) The facies classification of rocks. J. Geol. 57, 18-54.

- (1952) Chemical bonds and the distribution of cations in silicates. J. Geol. 60, 331-355.
- \& DeVore, G. W. (1951) The distribution of $\mathrm{Fe}^{++}$ and $\mathrm{Mg}^{++}$in coexisting olivines and pyroxenes. J. Geol. 59, 193-210.

Rimšaite, J. (1964) On micas from magmatic and metamorphic rocks. Contr. Miner. Petrol. 10, 152-183.

SAXENA, S. K. (1968 a) Nature of mixing in ferromagnesian silicates and the significance of the distribution coefficient. N. Jb. Miner. Mb. 1968: 8, 275-286.

- (1968 b) Distribution of elements between coexisting minerals and the nature of solid solution in garnet. Amer. Miner. 53, 994-1014.

- (1969) Silicate solid solutions and geothermometry: 3. Distribution of $\mathrm{Fe}$ and $\mathrm{Mg}$ between coexisting garnet and biotite. Contr. Miner. Petrol. 22, 259-267.

Schwander, H., Hunziker, J., Stern, W. (1968) Zur Mineralchemie von Hellglimmern in den Tessinalpen. Schweiz. Petr. Mitt. 48, 357-390.

SтÅLHös, G. (1962) Nya synpunkter på Sörmlandsgnejsernas geologi. Sveriges Geol. Unders. Ser C No. 587.

Sundius, N. (1923) Grythyttefältets geologi. Sveriges Geol. Unders. Ser C No. 312.

TAN, LI-PING (1968) Possibility of a garnet geothermometer. Proc. Geol. Soc. Cbina, 1968:12, 129-133.

Velikoslavinsky, D. A. (1965) Influence of rock composition and specific characteristics of metamorphism on the composition of pyralspite garnets. (In Russian). In »Regionalny metamorfizm dokembricheskikh formatziy SSSR». Ac. Sci. USSR., Izd. Nauka, Moscow.

Wones, D. R. \& Eugster, H. P. (1965) Stability of biotite: experiment, theory, and application. Amer. Miner. 50, 1228-1272.

Wright, W. I. (1938) The composition and occurrence of garnets. Amer. Miner. 23, 436-449.

Manuscript received, April 15, 1969. 